\title{
Creative EFL Writing as a Means of Intensifying English Writing Skill Acquisition: A Ukrainian Experience
}

\section{Oleg Tarnopolsky}

This article describes a classroom technique for improving the writing skills of EFL university students who have chosen English as their major for pursuing future careers as translators from and into English. The technique in question, designed for a creative writing course aimed at such students, was based on: (a) the combination of process and genre approaches to teaching writing; $(b)$ paying special attention to students' development of the skills of description, narration, and discussion in creative writing; (c) development the skills of commenting and critique; (e) emphasizing peer-reviewing, peer-commenting, and peer-evaluating students' written works in the course; (e) and ensuring learners' autonomy in writing by introducing free-choice writing. This technique allowed students to achieve dramatic improvement in their writing skills. The article describes how its introduction not only intensifies students' development, but also generates positive motivation for writing in English as a foreign language.

Cet article décrit une technique de salle de classe qui vise l'amélioration des aptitudes à écrire d'étudiants en ALE à l'université qui ont choisi la langue anglaise comme spécialisation et qui se destinent à une carrière en traduction. Cette technique, qui a été développée pour un cours de création littéraire, repose sur les cing démarches suivantes: (a) l'application d'une combinaison de deux approches (une basée sur le processus, l'autre sur le genre) à l'enseignement de la rédaction; (b) une attention toute spéciale portée au développement, chez les étudiants, d'habiletés de description, de narration et de discussion dans la création littéraire; (c) le développement des aptitudes à commenter et à critiquer; (d) une importance accordée à la révision, aux commentaires et à l'évaluation, par les pairs, des travaux écrits; (e) l'introduction de la rédaction à partir de choix libres pour encourager l'autonomie chez les étudiants. La mise en cuvre de cette technique a mené à des progrès très notables au niveau des aptitudes à écrire des étudiants. Nous expliquons que cette technique ne fait pas qu'intensifier l'amélioration des habiletés, mais qu'elle accrồt également la motivation d'écrire en anglais comme langue étrangère. 


\section{Introduction}

In ESL/EFL, teaching creative writing is usually defined as one that "suggests imaginative tasks such as writing, poetry, stories, and plays" (Harmer, 2001, p. 259). There is nothing surprising in the growing popularity of such writing in ESL/EFL teaching, first because of its motivational potential for learners. Writing a poem or a story in the target language is a great achievement for any student, something to be proud of, and "most people feel pride in their work and want it to be read" (Ur, 1996, p. 169). Besides, it is probably the most effective way of exploring the language in a playful and experimental way (Brauer, 1997), a way of discovery and self-discovery most suited to stimulating and intensifying language learning and/or acquisition. Therefore, creative writing may be considered an important part of any language program where learners are required to attain high levels of proficiency in the language being learned.

Regrettably, creative writing in English as a foreign language is practically unknown and unused in EFL teaching in Ukraine. This fact necessitates its introduction into EFL teaching there as one of the best ways of promoting and intensifying "students' linguistic and intellectual development by helping them to create L2 texts that come to reflect their maturity and expertise" (Leki, 2002, p. 9).

When planning the study on teaching creative writing in English to Ukrainian EFL learners, we thought it best to begin by introducing creative writing to university students who learn English for their future profession as EFL teachers, translators, and interpreters. These students have the highest level of motivation for learning English in comparison with other categories, and they are most inclined to exploring, discovering the language, and playing with it because their learning goals are not purely utilitarian. We also decided to start creative writing quite early: at the pre-intermediate stage of students' command of English. This was based on the results of my earlier study (Tarnopolsky, 2000), which suggested that students could demonstrate a high degree of creativity, fantasy, and imagination in their writings as early as the pre-intermediate level of learning English.

\section{Class Technique and Context}

The first distinctive feature of the technique for teaching creative writing developed for the study was the combination of the process approach (Tribble, 1996; White \& Arndt, 1991) and the genre approach (Swales, 1990). The combination of the process and genre approaches, strongly recommended by Tribble necessitates analysis of genre peculiarities in sample texts at the pre-writing stage and analysis of the same peculiarities and their norm-appropriateness in students' own pieces of writing at the post-writing stage. 
Two genres were selected for the study: a short story and a personalized psychological sketch (describing attitudes, feeling, and emotions stimulated by something; dreamtelling, etc.). These two genres were believed to be the most accessible and stimulating for the students at the given stage of learning. Writing in these two genres requires the development of abilities to describe, to narrate, and to discuss in L2 using the appropriate language means in a sufficiently expressive way to reveal adequately one's ideas, attitudes, feeling, and emotions. Therefore, the genre analysis was to be concentrated on description, narration, and discussion in short stories and psychological sketches written in English.

The next distinctive feature was the special attention paid to developing students' skills of commenting and critique in writing. These embody students' abilities of critical thinking, and without critical thinking (first, the ability to evaluate critically one's own works and the works of others), effective creative writing is not possible (see Kumaravadivelu, 1999; Johnson, 1999; Pennycook, 1999; Price, 1999; Ramanathan \& Kaplan, 1996, and others). To teach students a critical approach to their own writings, they should first be taught to think critically about and critically evaluate the writings of others, preferably their peers. The road to mastering this critical approach is acquiring the skills of commenting and critique, which should be developed from the start of creative writing.

This was the reason for introducing the fourth feature of the technique: emphasizing peer review, peer comment, and peer evaluation of students' written works in the course.

The introduction of the fifth feature of the technique was a result of the results of the previous study by Tarnopolsky (2000), which showed that learners were most highly motivated in their writing, most creative in it, and most efficient when they were autonomous or even independent in their choice of what to write about (topic) and how to write it (language, structure, style, etc.). Therefore, the fifth feature was to ensure learners' autonomy (Benson \& Voller, 1997) in writing. Autonomy was ensured by introducing free-choice writing, which presupposes learners' own and independent choice of topics and contents of their writings, as well as the language, style, and structure of what is to be written. The term free-choice writing was used rather than the generally accepted term free writing (Byrne, 1988; Raimes, 1983), which Raimes defines as the teaching approach where the focus is placed on content and fluency, with little attention paid to form.

The context for introducing the technique of teaching creative writing discussed above was, as stipulated, an EFL program for university students who learn English for their future professions. The particular program chosen for the study was one taught in a university in Dnipropetrovsk (Ukraine) in the department that trains translators and interpreters from and into foreign languages (mostly English). The students of that department 
would presumably be highly motivated to acquire the skills of creative writing in English in view of their future profession.

A specific group of students was selected for the study. The students in that small group (four students, all women, 18-22 years of age) were absolute beginners when they began learning English in the university. So whatever progress they achieved was the result of their studies in that particular program and could not be ascribed to any previous experience in acquiring the language. The choice of such a small group of learners was also believed to be beneficial as it allowed the work of each student to be more closely and carefully observed.

In the second year (2001-2002 academic year) of their studies, when the group in question started their pre-intermediate course in English, they had 14 hours of English classes per week during both semesters (252 hours per semester, 504 hours for the whole year). The study of teaching creative writing was carried out almost all the academic year from September 2001 until May 2002. Creative writing was taught as an autonomous "course within the course." Students completed their writing assignments out of class and independently of other assignments, but special classes were allocated for genre analysis, commenting, and discussing the pieces written.

\section{Approaching Creative Writing: The First Stage of the Course (Description and Discussion of Results)}

This part of the course was designed to prepare students (first psychologically) for creative writing in a language foreign to them: the kind of assignments they had never done before. The practical work at this stage was designed in the following manner. At the beginning of the term every student received a weekly assignment to write an essay of about 150-200 words. The topic of each essay was to be chosen by each student independently with no prompts or suggestions from the teacher. The aim was to develop students' total autonomy in writing, so no limitations were set for the choice of topic, form, or content. Students could write about whatever they wanted and however they wanted (free-choice writing in the sense explained above). The only external help given to the students was analyzing with them the peculiarities of writing texts of various genres.

The teacher-mostly in writing, but sometimes using oral comments that could be useful to all students-commented on every essay. The comments focused on the content and genre peculiarities of what had been written. The language forms were not focused on, except for correcting the most frequent and serious language errors: those that could cause incomprehension or misunderstanding of what had been written. All the other students in the group were also requested to read and comment on each essay in parallel with the teacher. The writer had to study all the comments and write a new 
draft using those of them that she agreed with. The second draft could be discussed and commented on again before editing if the writer desired. No grades were given to the students, but writers naturally perceived the comments of the teacher and the peers as evaluation of their work.

During the first month of work, the students' apprehension at the beginning of the activities was replaced with great interest and enthusiasm. Individual talks with the students (interviews) demonstrated that they had started to see their essays as a means of self-expression and self-assertion. Probably this attitude was the cause of rapid and intensive growth in the sophistication of the pieces of writing submitted to the teacher. The interviews revealed that students spared no time or effort in improving their pieces using dictionaries and other reference materials, comparing their own writings with those of the others and with the sample texts supplied by the teacher. Therefore, there was nothing surprising in learners' rapid language development and their development as writers. An example is provided by reproducing two essays by one of the students, Helen. ${ }^{1}$ One was written at the beginning of the term and the second two weeks later.

\section{Example 1}

\section{A little about me}

I hate a fashion. I hate when somebody shows me what I must to wear and what I don't. I don't understand, how one may to wear a thing, which doesn't like. The surpluses in clothes irritate me. I don't like bows, bright colours, shining and cheap things. I like a comfortable clothes, but stylish. I like a trousers, jeans, common blouses, jackets very much. I like a gut foot-wear. It mustes to be beautiful, comfortable. I love a perfume very much. I like different scents: spice of east tenderness, of flower, of plants.

But I don't like heavy scent. They prevent to breathe. I like to see the flame. It calms me. I respect strong people, I despise weak people. I like clever people, I tolerate stupid. I don't consider myself a clever girl, but I don't consider myself stupid. However, I don't decide it. OK. It's all for the present.

\section{Example 2}

\section{Pets in the town}

I suppose each animal must be of use. For exemple, the dogs guard a house from villains, the cats catch mice, the fishes calm nerves. But exist the people who are crazy about breeding animals. I object against pets. These pets do nothing, create a lot of problems and require a care of themselves. I can to understand these people, but I don't concern to them. I suppose the pets are a big responsibility. They require a lot of care. I love the pets in distance: I can to stroke if it is a cat or a dog but 
no more.

Pets in the town, especially small pets, are a part of furniture.

It's my personal opinion.

But for exemple, my sister supposes, each man must have a pet for people to be responsible and more humane. In her own way, she's right. That's why I don't want to push my opinion.

Although both essays were written just a couple of weeks apart, the differences between them are considerable. The first essay is rather primitive from the point of view of vocabulary and structures used, whereas the second one is much more sophisticated in that respect (see the use of words such as require, stroke, responsibility, humane, villain, create, exist; the use of such a structure as my sister supposes that each man must have a pet: all these language items were clearly beyond the learner's scope when she was writing her first essay in which she demonstrated no variety in the choice of verbs and employed only the verbs to like and to love to state her preferences). Second, there are fewer language errors although the essay is still full of them (e.g., to after can is still used, but after must it disappears, as well as the form mustes). Third, the second essay is on a considerably higher level in the content, logic, coherence, and cohesion of writing. It seems important that the student was able to make the transition from a comparatively simple description (of herself) in the first essay to discussion in the second: formulating her ideas clearly and finding and stating arguments in support of them. Therefore, the progress attained after a short time is quite obvious. Also obvious in both essays is the student's desire to express herself, to explain her outlook and attitudes.

All the features described above characterized the essays of the other students, which can be illustrated by the work called Colobok written by student Mary about two weeks after Helen wrote her second essay. (Colobok is traditional Russian bread-like food baked in a special manner. It is also the title of a well-known Russian fairy tale).

\section{Example 3}

\section{Colobok}

"Colobok, Colobok, I won't eat you."

When I was 4, my father served in Soviet Army in town of Cartaly. He went onto his 24-hour duties and my mom gave him his meals. As a little girl who loved her dad and had a little fantasy, I decided to cook something for him myself. I took some wheat flour, some water and some sugar and mixed it all diligently into one ball. I made two ears, one nose and two eyes. I put this so called "Colobok" in the oven and baked it for about 15 minutes. Then I took it out and wraped it nicely into a small handkerchief. I gave it to my dad and waited impationately 
for next day to come. My father returned and said, that my colobok was delicious and all officers asked him who gave it to him. And he answered proudly that it was his little daughter, who made it specially for him. I was so proud of myself and it was so pleasant to feel that all father's friends are so envious that only he had so kind and thoughtful daughter.

And only in many years I learned, that my Colobok was so hard, that my dad couldn't bite off a piece. Anyway, I think that my father did right not telling me that that cake was inedible. Otherwise, I would never cook anything again.

The essay in Example 3 has the same distinguishing features as those in Example 2 with the difference that it can be considered an example of narration. But it is a higher-level essay because it was written somewhat later in the course. The errors in grammar, if not absent, have become rare; the student's vocabulary is well chosen, varied, and filled with words unusual for a learner who has started learning to write in English only recently (diligently, delicious, envious, inedible). Colobok is a real short story in style and structure, having the plot and characters, the introduction, the development of events, and the conclusion. Therefore, during the first stage of their writing course the students learned how to write using description, narration, and discussion. The intensive development of their writing skills in general could be observed quite clearly.

\section{Writing Literary Works: The Second Stage of the Course (Description and Discussion of Results)}

The second stage of the course started in the third month of the same semester and continued until its end (two more months). The stage was devoted to developing learners' skills in writing "literary" works in L2. The students were requested to write such literary works once a week instead of essays with independently chosen topics. The other aspects of the technique used remained mostly unchanged. On the other hand, after passing to the stage of literary (creative) writing, evaluating and commenting on students' works was more elaborate than in the first stage.

Just as before, both the teacher and each student in the group commented on every student's work. But after the final draft of that work and its editing were completed on the basis of all the comments, a special class was held to discuss it and the works of all the other students written during a certain period. In this class, which was called a literary contest, each student read her work aloud trying to present it in the most expressive way.

Each student's presentation of each of her pieces of writing during all literary contests was made for the teacher and the students to compare the first drafts, which they had read and commented on earlier, with the final 
edited draft. After each presentation, every student discussed the work presented comparing her opinion of former drafts with the impression made by the final draft. The teacher did not take part in the discussion to avoid influencing the opinions of the students. Each speaker was to evaluate the final draft using a five-criteria scale: (a) contents (10 points maximum); (b) language and style (10 points maximum); (c) artistic impression (10 points); (d) impression made by the presentation of the work (10 points); (e) total impression (10 points). Therefore, the total possible score was 50 points.

The student who scored the most points was proclaimed the winner of that particular contest and received a special certificate made by the students themselves, this being a material sign of recognition of achievement. It is worth mentioning that the students were serious about their evaluations and awarding certificates, so this became an important stimulus for further enhancing learners' motivation and interest in creative writing.

To see the progress and results achieved by the students during this stage of the course, it is necessary to compare their works written at the beginning of the stage and at its end, which coincided with the end of the semester. The following work was the first literary work of one of the students, Lena.

\section{Example 4 (Lena)}

Lisa got up at 6 o'clock. She looked out of the window. The sun shone. Lisa went pensively along to the bath. From there she went out fresh and chilly.

While she luxuriated under streams of water, it was raining. Lisa sat down near the window. The water in the kettle boiled. Lisa stood up and came up to the stove. She made tea with strawberry. She sat down near the window again. The rain became stronger. The people ran fussy, hid under umbrellas. The roads sparkled, they were like varnished floor. Lisa wraped herself in the warm soft rug and tossed off a half of cup of tea at one gulp. She heard the telephone call.

-Hallo?

-It's me

-Why do you call?

-I need you. I need us.

-It's all over. Did you forget it?

-Lisa, I'm sorry.

-I hate you.

-Short hootings.

She hung up the receiver, drank the tea. She washed the cup. Then she came in her bedroom. She dressed her favourite dark blue dress, made up. The doorbell. Lise opened the door.

HE was on the threshold.

Wet to the skin, grimy. Loved.... The most handsome man in the world. 
Her man.

-I love you, Lise.

-I hate you. Kome in. Would you like tea?

Analysis of the work above leads to the conclusion that the creative approach has become more prominent than in the earlier essays. The same holds true of the student's aspiration to become more expressive with the aim of attracting the readers' attention-especially to the personality of the writer herself. This is the consequence of the more creative nature of the assignment and the reinforcement of competition. But the language has deteriorated somewhat compared with earlier essays (see, e.g., the essay by Mary in Example 3). The reason for this deterioration seems to lie in the greater difficulty of the new type of assignment combined with the learners' focusing on content and expressiveness and paying much less attention to the language form. It was also anticipated that the language would improve gradually and spontaneously as the students practiced creative writing and self-editing.

In fact this assumption proved correct, and the proof can be found in the final works written by the students at the end of the semester. The final for that semester and probably the most typical work of one of the students, Mary, is given as an example to demonstrate the students' general level of creative writing two months after the first literary works were written.

\section{Example 5}

I had to fly again. I hate flying. I'm airsick, I don' like stewardesses and the way they talk to passengers (We are not ill kids!!!). The meal is always not to my liking and be sure it will be cold as a stone. And I always (ALWAYS!) have strange people in the neighbourhood. Last time it was a corpulent man who snored deafening all flight long. And the flight before last was awful! One of my neighbours talked in his sleep. So I know now all his little empty secrets.... Even now I remember his stupid round face, turned-up nose and deep wrinkles around the mouth. It is so easy to distinguish a dull, malevolent, worthless person. By the way, it's so exciting to define the main point of any person just having a glance on him. For instance, that guy on the left. I hate men who are weak ... narrow shoulders, too thin fingers, too big nose. He's so skinny that it seems the wind would take him easily if he left his keys at home. What kind of woman can it be to find him interesting? Even his eyes don't dare to look at me straight. Of course he likes me ... It makes me so tired ... Why only the mongrel like him try to please me? Where are the Men? The Real Man? And this one ... a gray narrowminded person, whose interests can be just in service to his boss and his grand mom still asks him what he had for lunch. By the way ... why 
that daubed doll, the head stewardess fusses over him? ... He doesn't look like a president, that's for sure! She offers him tea for a hundredth time! I'm thirsty too, by the way! No, there IS something in her behaviour beyond doubt! I have to know what's the story! Or I'm not myself!

-Excuse me! May I have a cup of tea? Thank you. I see our plane is in skillful hands! I love flying. I always feel almost like a bird when I'm on board. And one can meet so many interesting people! Oh ... I'm eager to know who's this young man on my left?

-Oh. Of course ... But ... Didn't you know? It's John Black!

—Who??? ... J ... John Black ... Oh my goodness! I've never seen him before ... John Black ... (“OK, don't worry, my dear! We'll make it! Where is my most charming smile? ...").

-I beg your pardon, sir. Do you have any extra plaid? It's quite cold here ... don't you think so? I'm almost frosen.

Comparison of the work above with the earlier examples shows considerable progress achieved during the two months that elapsed. Great progress is shown in the quality of language in the pieces being compared. Thus it can be asserted that creative writing was an effective stimulus for intensified development of the grammatical and pragmatic components of the learners' communicative competence. As assumed, development mostly happened spontaneously thanks to the learners' practice in production. The last work shown above also manifests considerable progress in acquiring the skills of expressing thoughts and ideas in writing: cohesion and coherence, appropriate and adequate structuring, developed abilities of using narration, description, and discussion where needed. Greater literary maturity is also shown.

I conclude that during the period under discussion (the pre-intermediate level of mastering English) the principal features of students' skills in creative writing were intensively developed. The improvement of these skills was set as the task of the third final stage of the study, which was planned for the second semester of the academic year and coincided with the students' transition from the pre-intermediate to the intermediate level of learning English. In the final stage the students had one more task besides polishing their creative writing: to further develop their skills in commenting and critique.

\section{Developing Skills in Commenting and Critique: The Third Stage of the Course (Description and Discussion of Results)}

This stage was similar to the preceding one in the learning activities used, but with special emphasis on writing paragraphs of comment and critique on other students' works. 
The results achieved by the end of the semester both in polishing students' skills of creative writing and in developing their skills of commenting and critique are best illustrated by two examples. The first is a short story, and the second is its critique.

\section{Example 6 (a story written by Mary)}

It was a small pale yellow piece of cheese. Its scent was teasing. Its holes were big. He was looking at it as though he was going to eat it with his eyes. He smelt it with his eyes closed. Then he took a knife, sharp and thin, and cut a tiny slice. He smelt it again and put it into his mouth not chewing it at first. With his eyes still closed, he swallowed the piece. For a couple of moments he stayed motionless enjoying the taste. Then, with a very serious face and accurate movements, he cut another slice, and smelt it again. He wasn't in a hurry. He wanted to enjoy this cheese to the last piece, wanted to get every single bit of its delicious taste, wanted to soak up everything from this terribly expensive dainty. She didn't eat the cheese at all. She wanted him to have it. No, she didn't sacrifice anything. Because she was looking at him and her heart was happy.

\section{Example 7 (critique of the story written by Helen)}

It was unusual. It was delicious. It was the first Mary's story with something like love. It wasn't horror story! Yes! Yes! Yes! I liked that. I always enjoy such stories. First because they are so exciting. Second I like love in all its varieties. Mary's stories are pleasure for me because they don't have any mistakes. I mean both grammar and vocabulary. More than that I always meet new words and grammar structures in Mary's stories because I learn words while I'm reading. I like Mary's way of thinking. It's close to mine. At first her stories go one way and then they turn in an unexpected way. It's a pity I can't write following this way of thinking.

All in all I hate Mary because she doesn't give me any chance to criticize her stories.

The above two examples show that by the end of the third stage of the course, its goals might be considered as attained. The students had developed the skills of writing sophisticated creative English texts adequately using the language and its grammatical, syntactical, lexical, and stylistic means for expressing their ideas, feeling, and emotions. They showed creativity and even certain literary abilities that allowed them effectively to describe, narrate, or discuss when writing in English. They had also acquired the basic skills of critique and of commenting on others' writing. 
There is no doubt that the learners' written English was far from perfect. But the results demonstrated in the examples above were achieved after learning English for little more than one year. Such results after such a comparatively short time are extraordinary for EFL and can be attributed primarily to the success of the suggested creative writing course.

\section{Conclusion}

The study demonstrates that creative writing is something that should be taught to all future professionals in the area of language (whether L1 or L2): specifically to future EFL teachers, translators, and interpreters. This is first, because creative writing is a unique means of mastering how to operate the language in the subtlest and most skillful manner, and second, because learners of EFL who choose it as their future profession have sufficient learning time and motivation to acquire English creative writing skills.

The study also shows that for such students developing their creative writing skills can be started at an early stage of EFL learning: immediately after they have passed from the elementary to the pre-intermediate level. It requires a specific creative writing course in the general course of EFL, which greatly intensifies the acquisition of writing skills.

\section{Note}

${ }^{1}$ All the students whose works are cited received a detailed explanation of the purpose and format of this article and were asked for permission to reproduce their writings in it. All of them willingly granted such permission but preferred their real names to be changed to pseudonyms, which has been done accordingly. The students' writings are reproduced just as they were written with no changes or corrections.

\section{Acknowledgments}

I thank my colleague Yulia Degtiariova, a senior instructor of English in Dnipropetrovsk University of Economics and Law for her assistance in collecting material for my study when she was teaching the third stage of the course described in this article.

\section{The Author}

Oleg Tarnopolsky is a full professor in Dnipropetrovsk University of Economics and Law (Ukraine) where he chairs the Department of Applied Linguistics and Methods in Foreign Language Teaching. His interests focus on EFL teaching. He has published books and numerous articles in Ukraine, Russia, the United States, the United Kingdom, France, Spain, Poland, Finland, Switzerland, Greece, the Netherlands, and Austria.

\section{References}

Benson, P., \& Voller, P. (Eds.). (1997). Autonomy and independence in language learning. London and New York: Longman.

Brauer, G. (1997). Schreiben im Fremdsprachenunterricht? Die Unterrichstpraxis (Teaching German), 30, 1-7.

Byrne, D. (1988). Teaching writing skills. London: Longman.

Harmer, J. (2001). The practice of English language teaching (3rd ed.). Harlow, UK: Longman. 
Johnson, B. (1999). Putting critical pedagogy in its place: A personal account. TESOL Quarterly, 33, 557-565.

Kumaravadivelu, B. (1999). Critical classroom discourse analysis. TESOL Quarterly, 33, 453-484.

Leki, I. (2002). The challenges of teaching English as a foreign language writing in the new century. In Abstracts of papers read at the international conference "Innovative Approaches to Teaching Foreign Languages and Cultures in the New Millennium" (pp. 7-10). Dnipropetrovsk: Dnipropetrovsk University of Economics and Law.

Pennycook, A. (1999). Introduction: Critical approaches to TESOL. TESOL Quarterly, 33, 329-348.

Price, S. (1999). Critical discourse analysis: Discourse acquisition and discourse practices. TESOL Quarterly, 33, 581-595.

Ramanathan, V., \& Kaplan, R.B. (1996). Some problematic "channels" in the teaching of critical thinking in the current L1 composition textbooks: Implications for L2 student-writers. Issues in Applied Linguistics, 7, 225-249.

Raimes, A. (1983). Techniques in teaching writing. New York: Oxford University Press.

Swales, J. (1990). Genre analysis: English in academic and research settings. Cambridge, UK: Cambridge University Press.

Tarnopolsky, O. (2000). Writing English as a foreign language: A report from Ukraine. Journal of Second Language Writing, 9(3), 209-226.

Tribble, C. (1996). Writing. Oxford, UK: Oxford University Press.

Ur, P. (1996). A course in language teaching. Cambridge, UK: Cambridge University Press.

White, R., \& Arndt, V. (1991). Process writing. Harlow, UK: Longman. 